\title{
The Effect of Togok Tendency Towards Placement of Service in FIK UNP Students
}

\author{
Indri Wulandari ${ }^{1 *}$, Muhammad Arnando ${ }^{2}$, Aldo Naza Putra ${ }^{3}$, Dessi Novita Sari ${ }^{4}$, Haripahlawanis ${ }^{5}$, \\ Hilmainur Syampurma ${ }^{6}$, and Frizki Amra ${ }^{7}$
}

${ }^{1234567}$ Dept. of Physical Education, Padang State University, Padang, Indonesia

*Corresponding author. Email: Indriwulandari@fik.unp.ac.id

\begin{abstract}
This research is a correlation study which aims to see how much influence togok flexibility has on the placement of service for sports education students at the Universitas Negeri Padang. The data was collected using a test survey with test and measurement techniques. Sampling was done using techniques Purposive Sampling totaled 30 people. The instrument test in this study used a Flexiometer to test the flexibility of the togok, and the Hewitt test achievement to test the placement of service. The results of the study concluded: 1). Togok's flexibility has directly affected Placement of service.
\end{abstract}

\section{Keywords: Select Togok, Placement of service}

\section{INTRODUCTION}

Service is a unique shot and easy to learn but not an easy thing to place this ball shot in the desired area. This service is important in the game of tennis and is the only stroke that must be mastered and controlled by a tennis player, this stroke is not affected by or depends on the ball hit the opponent. Service as the first attack, every tennis player must master service well in order to adjust the game pattern. The first attack with service can be done by performing hard service or placing the service in a place that is difficult to reach, making it difficult for the opponent to receive service. Therefore, Placement of service is needed to be able to get the opportunity to make the first attack.

Melvin H. William (1990: 87) states that flexibility is very useful in preventing injuries and correcting bad posture. The service stroke requires good flexibility because if at the time of service the flexibility is not good or stiff, the result of the service stroke will not be perfect. A tennis player in providing good service must also have good flexibility because a large and balanced togok flexibility will produce quick bursts and can help direct the ball to the desired place. This fact is reinforced by an expert who says how with a bouncy attitude that will increase the power of service power, the resilience produces the force that pushes the racket head. Togok flexibility in the game of tennis can also be interpreted as a means of moving optimally by the muscles and joints of the body.

Talking about court tennis, tennis is one of the courses included curriculum of FIK, Universitas Negeri Padang. Tennis court courses are included in practical courses that are difficult for students, especially in obtaining perfect scores. It is not an easy matter to be able to play tennis in 6 months, especially if you start at an age that is no longer a teenager. During lectures, every student is required to have a good power, endurance, explosive power, speed, agility, hand eye coordination and flexibility. In addition to these components of the physical condition, self-confidence and intelligence are needed in analyzing every movement that is made.

There are several basic techniques of playing tennis that must be learned and trained by every student, namely; Forehand, Backhand, volley, Service, and these basic techniques have their respective difficulty levels. Among the basic techniques above, service is the easiest technique to learn. Service is the opening stroke in a tennis court game, besides that the Placement of placing service when playing is also very important, so that the opponent has difficulty turning the ball. Placement of service is no less important than speed of service, why? Because not everyone can hit service very hard and fast. For those without hitting power, being able to put service hits out of reach is a great strategy to make it easier to get points. To examine the needs in supporting the success of Placement of service, every student must have a good physical condition component and selfconfidence that determines the level of success. Here the researcher wants to know which types of physical condition components determine the placement of service and how much the influence of self-confidence is, so the specific goals of this research is to see the 
effect of Togok Flexibility, on placement of service in FIK UNP students.

\section{METHOD}

The research method used in this research is a quantitative approach, a survey method with measurement and test techniques, while the analysis technique uses a correlation approach, which is a technique for correlation the causal relationship that occurs in multiple regression if the independent variable affects the dependent variable not. only directly but also indirectly, supardi. So, the correlation model is used to analyze the pattern of relationships between variables in order to determine the direct or indirect correlation of a set of independent (exogenous) variables on the dependent (endogenous) variable. The variables studied consisted of four variables consisting of three exogenous variables and one endogenous variable. The exogenous variables consisted of togok flexibility (X), Endogenous variables consist of Placement of service (Y). The pattern of the relationship between the research variables ;

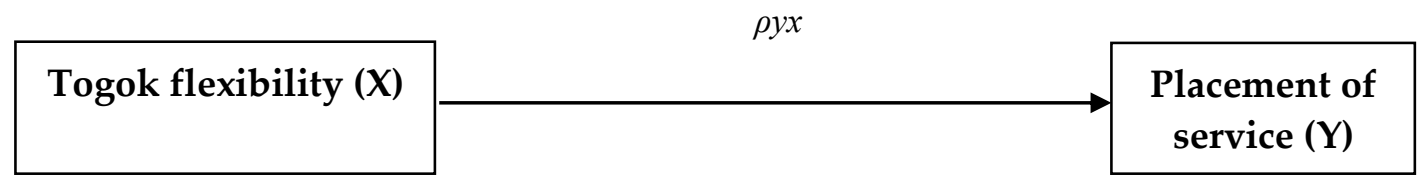

Figure 1. Constellation of Correlation techniques for the hypothesis $X$,and $Y$

Information:

X: Togok flexibility

Y : Placement of service

\section{RESULTS AND DISCUSSION}

\section{A. Result}

The description of the data from the research results aims to provide an overview of the distribution of data distribution, both in the form of a measurement of the location of the frequency distribution. Prices presented after being processed from raw data using descriptive statistical methods, namely maximum value, minimum value, range, average, standard deviation and variance. The summary of the results of statistical calculations is as follows:

Table 1. Summary of Research Results

\begin{tabular}{|l|c|c|}
\hline \multirow{2}{*}{\multicolumn{1}{|c|}{ Statistics }} & \multicolumn{2}{c|}{ Variable } \\
\cline { 2 - 3 } & X1 & Y \\
\hline Number of Samples (n) & 30 & 30 \\
\hline Maximum Value & 44 & 27 \\
\hline Minimum Value & 25 & 13 \\
\hline Range & 19.00 & 14 \\
\hline Average (X) & 36.37 & 20.90 \\
\hline Standard Deviation (s) & 6.34 & 3.66 \\
\hline Variance (s2) & 40.17 & 13.40 \\
\hline
\end{tabular}

Based on statistical results descriptive above, it can be analyzed that:

\section{Placement of Service (Placement of service) (Y)}

Based on research data regarding Placement of Service (Placement of service) (Y) obtained the lowest score 13 , the highest score 27 , so that the range is obtained 14. From statistical calculations obtained an average value of 20.90, the standard deviation (SD) of 3.66 and the variance of 13.40 . To provide an overview of raw data Placement of Service (Placement of service) (Y) can be arranged the frequency distribution;

Table 2. requency distribution Placement of Service (Placement of service) (Y)

\begin{tabular}{|c|c|c|}
\hline Interval Class & $\begin{array}{c}\text { Freq. } \\
\text { Absolute }\end{array}$ & $\begin{array}{c}\text { Freq. } \\
\text { Relatively }\end{array}$ \\
\hline $13.00-15.39$ & 2 & $6.7 \%$ \\
\hline $\begin{array}{l}-\quad 17.79 \\
\end{array}$ & 3 & $10.0 \%$ \\
\hline $17.80-20.19$ & 9 & $30.0 \%$ \\
\hline $20,20-22.59$ & 6 & $20.0 \%$ \\
\hline$-\quad 24.99$ & 4 & $13.3 \%$ \\
\hline $25.00-27.39$ & 6 & $20.0 \%$ \\
\hline Total & 30 & $100 \%$ \\
\hline
\end{tabular}

Of the 30 research samples, if the results of each respondent were compared with the average, it turns out that those who did Placement of service $(\mathrm{Y})$ in the group had an average of $6(20.0 \%)$, were below the average group of $14(46.7 \%)$, and $10(33.3 \%)$ were in the above average group. The results of the research on 
the results of the placement of service (Y) can be displayed in the following histogram form:

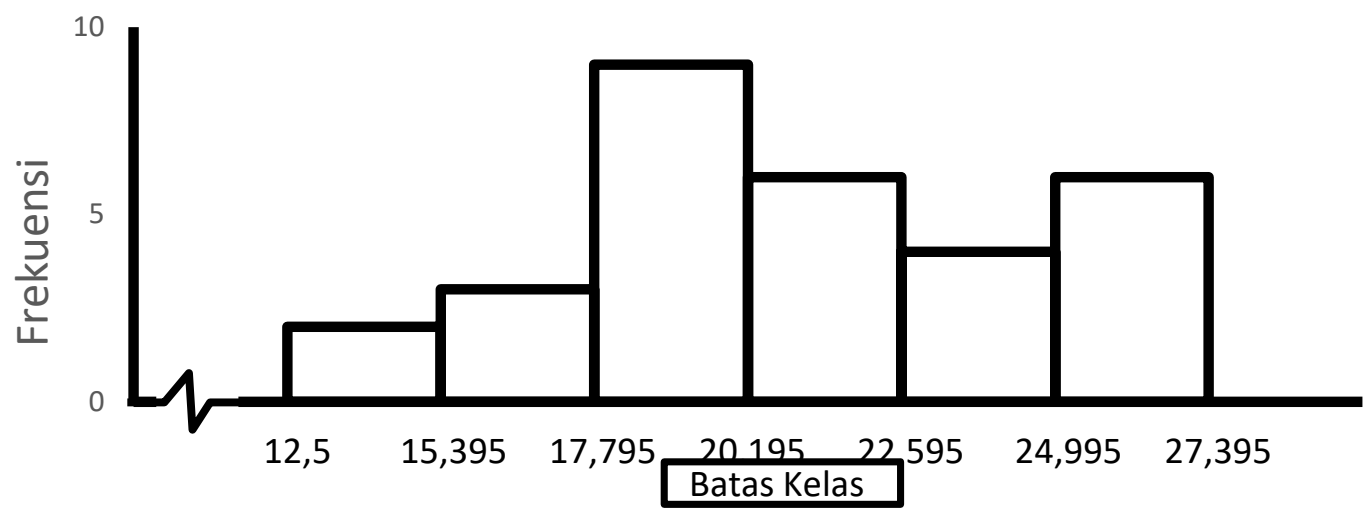

Figure 2. Histogram Placement of Service (Placement of service) (Y)

\section{Togok flexibility (X1)}

Based on research data regarding Togok flexibility $(X)$ obtained the lowest score of 25 , the highest score of 44 , so that the range was 19 . From statistical calculations, the average value was 36.37 , the standard deviation (SD) was 6.34 and the variance was 40.17. Overview data Togok flexibility $(\mathrm{X})$ can be arranged the frequency distribution.

Table 3. Distribution Togok flexibility (X)

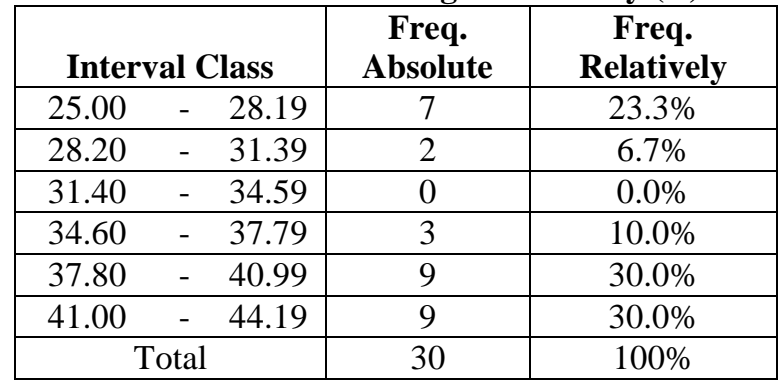

Of the 30 research samples, if the results of each respondent are compared with the average, it turns out that they get Togok flexibility $(X)$ in the average group $3(10.0 \%)$, were below the average group of $9(30.0 \%)$, and $18(60.0 \%)$. Results of research about results Togok flexibility $(\mathrm{X})$ can be displayed in the following histogram form:

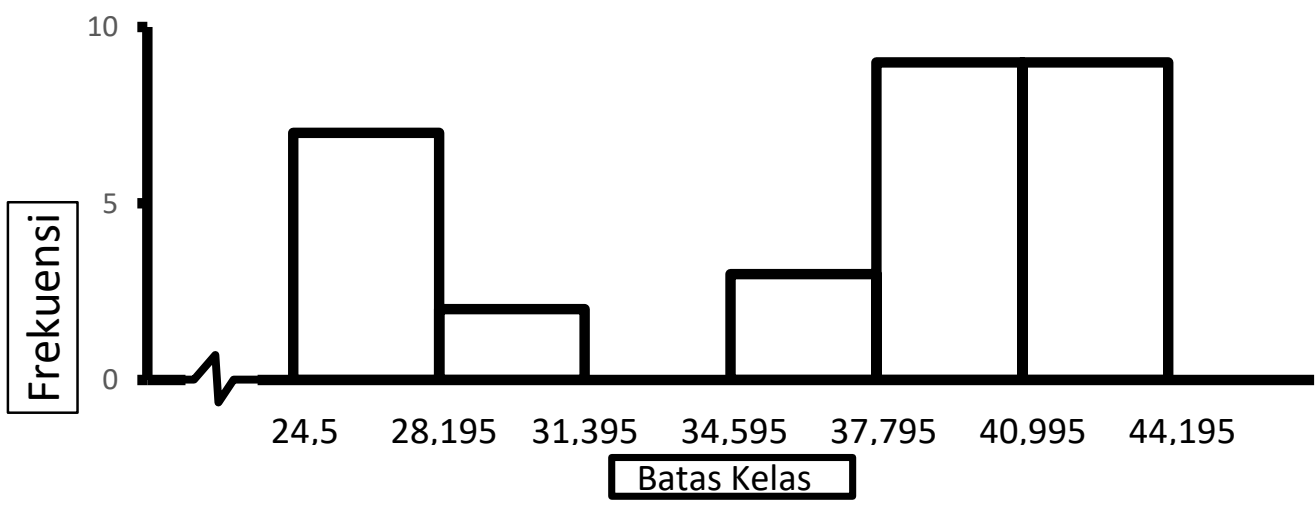

Figure 3. Histogram of Togok Flexibility (X1) 


\section{Discussion}

First, the hypothesis has a significant effect on Togok Flexibility, on Placement of service. After testing the hypothesis together it is significant when the individual test is significant. Based on the results of individual hypothesis testing, it turns out that Togok's flexibility has a significant effect on Placement of service Student of UNP Tennis Subject. Structural equations the results of the correlation of the Togok Flexibility, the results Placement of service is as follows: $\mathrm{Y}=0.187 \rho 1 \mathrm{y}+0.18 \rho 2 \mathrm{y}$. The correlation of the Togok Flexibility variable $(\mathrm{X})$ on Placement of service $(\mathrm{Y})$ directly equal to $0.3242 \mathrm{x}$ $100 \%=0.1049$ or $10.49 \%$. Other variables that can affect Placement of service among others, performing service punches effectively and efficiently in accordance with the following stages: body position, contact points, arm strength, and speed in achieving maximum service strength.

\section{CONCLUSIONS}

Conclusions were drawn research findings with exogenous variables consisting of Togok Flexibility (X), consist of Placement of service (Y).

There is a positive influence between Togok Flexibility (X) on Placement of Service (Y)

Thus the Placement of service to Students can be increased through increasing Togok Flexibility.

\section{ACKNOWLEDGMENTS}

We would like to thank for this research: The Research Institute and Community Service of UNP who have funded this research, the academic community and all UNP students who have been willing and participating in this research process. And also has given permission to carry out research at the Indoor Tennis Court, Padang State University.

\section{REFERENCES}

[1] A Chu, Donald. 2007. Tenis Tenaga. Jakarta. PT. Rajagrafindo Persada.

[2] Adnan Aryadie. 2005. Tes dan Pengukuran Olahraga. Padang: Fakultas Ilmu Keolahragaan Universitas Negeri Padang.

[3] Agus, Apri. 2012. Olahraga Kebugaran. Padang: PT. Sukabina Press.

[4] 2015. Dasar-dasar Permainan Tenis Lapangan. Padang: PT.Sukabina Press.

[5] Boyke, Adam. 2011. Hubungan antara Kelentukan Togok, Koordinasi Mata-Tangan dan Motivasi Berprestasi Terhadap
Keterampilan Servis Tenis Pada Atlet Marison Tenis Club. Brown, Jim. Tennis Steps to Success. USA. Human Kinetik, 2004.

[6] . Tenis Tingkat Pemula. Jakarta: PT. Raja grafindo Persada, 2007.

[7] Greenwald, Jeff. 2009. 50 cara mengubah kekurangan menjadi kelebihan (The best Tennis in Your Life). Betterway Books.

[8] Giampaolo, Frank and Levey, Jon. 2013. Championship Tennis. Canada: Human Kinetic. 2013

[9] Irawadi, Hendri. Cara Mudah Menguasai Tenis. Padang: Wineka Media Malang. 2009.

[10] Irawadi, Hendri. Kondisi Fisik dan Pengkurannya. Malang: Winekamedia, 2011.

[11] Komarudin. 2013. Psikologi Olahraga:latihan mental dalam olahraga kompetitif. Bandung:PT. Remaja Rosdakarya

[12] Lardner, Rex.Fundamental Tenis. Semarang: Dahara Prize, 2013.

[13] Miller.K.David. 2006.Measurement By The Physical Educator: why and how. (Intenational fifth Edition. McGraw Hill)

[14] Riduwan, Engkos Ahmad Kuncoro. Cara Menggunakan dan Memaknai PathAnalysis. Bandung: ALFABETA, 2012.

[15] Roetert, Paul dan Kovacs, Mark. Tennis Anatomy: Human Kinetics. USA. 2011.

[16] Sawali La. Disertasi. Pengaruh Strategi Latihan dan Kekuatan Lenganterhadap Keterampilan Forehand Drive dalam Permainan Tenis Lapangan. PPs. UNJ, 2004.

[17] Shcoll, Peter. Tennis. Munich, Wina Zurich: BLV Verlagsgesellschaft mbH. 2002.

[18] Sugiyono, Statistik Untuk Penelitian, (Bandung: Alfabeta, 2010

[19] Supardi, Aplikasi Statistik Dalam Penelitian, (Jakarta Selatan :UFUK Press, 2012)

[20]Syafruddin. Dasar-dasar Ilmu Melatih. Padang: Fakultas Ilmu Keolahragaan Universitas Negeri Padang, 2012.

[21] Tangkudung, James. Kepelatihan Olahraga "Pembinaan Prestasi Olahraga" Edisi II. Jakarta: Cerdas Jaya, 2012.

[22] Undang-Undang Sistem Keolahragaan Nasional Nomor 3 Tahun2005 tentangPembinaan dan Pengembangan Olahraga Prestasi.

[23] Widiastuti. Tes dan Pengukuran Olahraga. Jakarta: Bumi Timur Jaya, 2015 